\title{
ESTIMATION OF HYDRAULIC PROPERTIES FROM PUMPING TESTS DATA OF NAIROBI AREA, KENYA
}

\author{
Steven.O. Owuor ${ }^{1^{*}}$, Christoph Schüth ${ }^{2}$, Rouwen J. Lehné ${ }^{3}$, Andreas Hoppe ${ }^{4}$, Joshua .Obiri ${ }^{5}$, \\ Daniel M. Nyaberi ${ }^{6}$, Monicah K. Kibet ${ }^{7}$ \\ ${ }^{1,2,3,4}$ Technical University of Darmstadt, Germany \\ ${ }^{5}$ Maseno University, Kenya. \\ ${ }^{6}$ University of Eldoret, Kenya \\ ${ }^{7}$ Kenya Electricity Generating Company \\ [*] Now at South Eastern Kenya University, Kenya \\ Correspondence to: S.O.Owuor (okothanumo@yahoo.com)
}

\begin{abstract}
The aim of this study was to determine the hydraulic properties of Nairobi area in order to highlight the groundwater potential and to identify the distribution of hydraulic characteristics of aquifers in the area as well as to highlight vulnerability of the aquifer to heavy abstraction. Documented pumping tests data of boreholes located in Nairobi County were analyzed. Pumping test data from eighty four (84) single-well boreholes were analyzed in AQTESOLV software to determine transmissivity and storativity using Cooper-Jacob's, Theis's, Papadopolus-Cooper's and Theis's recovery methods. Hydraulic conductivity was calculated based on the relationship between hydraulic conductivity and transmissivity. The values of transmissivity for all wells ranged between 1.11 and $360.58 \mathrm{~m}^{2} / \mathrm{d}$ by using Theis -and Cooper-Jacob methods, 1.10 and $360.58 \mathrm{~m}^{2} / \mathrm{d}$ by Papadopulos-Cooper method and between 1.289 and $677.81 \mathrm{~m}^{2} / d$ by Theis recovery method. The city of Nairobi faces increasing ground-water demand due to ever rising population which is mainly driven by rural-urban migration and industrial growth. Surface water has not only been over-stretched but also heavily polluted and unreliable thus groundwater is the only reliable alternative source of water in the area. Lava and pyroclastic formed during Cenozoic age make up the geology. Under these lavas and pyroclastic rocks lie schists of Precambrian age and gneisses of Mozambique belt of the same age. These results indicate that the aquifer is heterogeneous and that the groundwater supply for local water supply (small communities and plants) is reliable but withdrawal for great regional supply is limited.
\end{abstract}

Keywords: Hydraulic Properties, Groundwater Management, Igneous Rocks, Pumping Test, Nairobi

\section{INTRODUCTION}

The ever growing population of Nairobi puts a lot of pressure on the groundwater water resources because surface water has not only been over-stretched but also heavily polluted thus unreliable leaving groundwater as the only reliable alternative in terms of quantities that meet the demand of the residents as well as suitable and acceptable quality (Coetsiers et al., 2008). The choice of original location of Nairobi city is one of the factors that contribute immensely to its perennial water shortage. The original planning of the city only took into account was a smaller population, however; today large population occupies the city due to its metropolis nature. Nairobi city is not only principal urban center of population but also the social, economic and communication hub of the whole country. Like any other city of the world it is faced with the problem of ever growing population, in 2010 Kenya National Bureau of Statistics (KNBS) reported the population of the city to be $3,138,369$. The high population has strained the water resources in this city.

Since the $20^{\text {th }}$ Century, development of groundwater has been carried out in Nairobi and its environs even though the understanding of the quantity and quality of the groundwater in the area remain very scanty. The assumption of unlimited resource has dominated this development (Coetsiers et al., 2008). The already poor health conditions in the slums continue to deteriorate as a result of urbanization which pushes poor city residents to the slums which face acute water shortage and poor dilapidated sanitation infrastructure. The city of Nairobi is supplied with both surface and groundwater, with most of the water utilized in Nairobi obtained from Tana River Catchment (Foster and Tuinhof, 2005). Surface water originally considered as freshwater from three main rivers: Nairobi, Mathare and Ngong and their tributaries that flow through Nairobi are currently highly polluted. Unfortunately, these polluted rivers continue to be heavily utilized by the poor residents in the slums and suburbs as their leading source of water. Dams such as Ndakaini and sasumua are also a major of the water supply in the city.

The city suffered severe drought in 2009 due to delayed 2008 October-December rains. The drought led to falling of water level in major dams like sasumua which is a major source of water supply of the city. In order to alleviate the water shortage, the Government of Kenya through the Ministry of Water and Irrigation drilled approximately fifty (50) boreholes in Nairobi. Borehole drilling in Nairobi area 
is increasing rapidly also due to increase in the demand of water supply for rapidly growing population, industrialization, agriculture and alternative to contaminated surface water thereby posing a threat to groundwater exploitation. Ministry of Nairobi Metropolitan Development (2008) projected that the domestic water demand will be about 900 million $\mathrm{m}^{3}$ by 2030. According to World Bank report number 28398-KE (2004), Kenya is classified as chronically water - scarce in absolute and relative terms. It is estimated that the country's renewable fresh water endowment stands at $518 \mathrm{~m}^{3}$ per capita per year, against the UN recommended threshold of $1000 \mathrm{~m}^{3}$ (Kenya State of Environment, 2011). By 2025, Kenya is projected to have renewable freshwater supply of $235 \mathrm{~m}^{3}$ per capita per year (Ministry of Water and Irrigation, 2007). Analysis of pumping test has proved to be one of the most effective methods for understanding hydraulic characteristics of aquifers (Kruseman and de Ridder, 1990; Delleur, 1999). Many groundwater studies have emphasized on qualitative investigation (Coetsiers et al., 2008; Nair et al., 1984); however, for holistic understanding of groundwater resources, quantitative assessment is paramount. Hydraulic parameters of an aquifer indicate its significance (importance) through portraying its water storage and transmission ability.

The aim of this study was to determine the hydraulic properties of Nairobi area in order to highlight the groundwater potential and to identify the distribution of hydraulic characteristics of aquifers in the area as well as to highlight vulnerability of the aquifer to heavy abstraction to ensure best practices in utilization of the current available water resources taking in to account the needs and interests of future generation.

\section{MATERIALS AND METHODS}

\subsection{Study area}

The city of Nairobi is bounded by latitudes $1^{\circ} 9^{\prime} \mathrm{S}, 1^{\circ} 28^{\prime} \mathrm{S}$ and latitudes $36^{\circ} 4^{\prime} \mathrm{E}, 37^{\circ} 10^{\prime} \mathrm{E}$ (Figure 1). The total area of the city is approximately $696 \mathrm{~km}^{2}$ (CBS, 2001). According to Mitullah (2003) the altitude of the city range from 1,600 to $1,850 \mathrm{~m}$ above the sea level with the high western side having altitude ranging from 1,700 to $1,800 \mathrm{~m}$ above sea level while the low eastern side is approximately $1600 \mathrm{~m}$ and sometimes flat as observed by Saggerson (1991). The close proximity of Nairobi to the Rift Valley makes the city to experience tremors and minor earthquakes (Onyancha et al., 2011).

Nairobi has a temperate tropical climate. Data record for 50 years from Kenya Meteorological Department (2001), show that Nairobi is characterized by mean minimum temperatures of $11.5^{\circ}$ to $14.4{ }^{\circ} \mathrm{C}$; and mean maximum temperatures ranging from $22.3^{\circ}$ to $28{ }^{\circ} \mathrm{C}$. Low temperatures are registered during the cool, dry and rather cloudy months of June to mid - October; with mean maximum temperatures of $22.3^{\circ}$ to $25.3{ }^{\circ} \mathrm{C}$. High temperatures are recorded in the months of mid - December to mid - March, with mean maximum temperatures in the range of $26.8^{\circ}$ to $28{ }^{\circ} \mathrm{C}$. The weather could be generally described as warm to hot, and dry with sunny days during this latter period of the year.

The coldest month is July with an average monthly temperature of $16.9^{\circ} \mathrm{C}$; while the hottest month is March with an average monthly temperature of $20.9^{\circ} \mathrm{C}$. The mean monthly range across the year is from $9.2{ }^{\circ} \mathrm{C}$ in November to $14.6^{\circ} \mathrm{C}$ in February.

\subsection{Data Collection}

The available borehole completion reports in the Ministry of Water and Irrigation were collected for this study. To supplement the collected data, fieldwork was carried out from $19^{\text {th }}-22^{\text {nd }}$ June 2012. A total of twelve (12) boreholes were sampled. Their positions were obtained using GPS. Information gathered throughout the course of this study was stored in ArcGIS 10, a Geographical Information System (GIS) for use as graphical database and ease of data presentation and analysis. Well logs were compiled and stored using GeODin software.

Data for boreholes used in this study were drilled and test pumping performed between 2007 and 2012. In principal, pumping tests were performed as follows:

Boreholes were drilled, cased and developed. After completion of the boreholes, submersible pumps and dipping pipes were installed and pumping test was done. The pumps were installed at positions which were determined by specific casing design of each borehole during drilling. The submersible pumps were powered by diesel generators. Before the pump was switched on, static water levels in all the boreholes was measured and recorded. The rate of water flow was regulated with a control valve. The pumped water was conveyed by discharge pipe to a point where it could not recharge the well under investigations. The steps involved in performing the pumping test were: measurements of water level changes in the borehole with time as pumping progressed; and recovery measurements which consisted of measuring the rebound of water level towards the pre-existing conditions immediately following pumping.

Data measurements taken during the pumping test were: water levels, time, and flow rates. Depth to water level in each borehole was measured with water-level meter which was either electric sounding and/or lighting dipper. A PVC dipper tube was installed alongside the test pump rising main and tied securely to it. Each borehole was pumped at a constant rate for 24 hours and water-level measurements were taken at regular time intervals and recorded. The constant pumping rate for each borehole was based on the yield which was estimated during drilling period. Water that was pumped from the boreholes were discharged to waste at a distance and in a manner that it did not pond or flow back towards the borehole under test. All time measurements were done by means of a stopwatch.

20 liters calibrated container was used to measure the flow rate (discharge) of the boreholes. The container was placed under the discharging pipe and time taken to fill it recorded and used to calculate the discharge.

After the pumps were shut off, recovery measurements were taken for additional 1-3 hours depending on the recovery rate of individual boreholes. The secondary data (available 
data) was found collected from borehole completion reports in hard copy. The data was first typed in Microsoft Excel 2010 and saved as .txt files which were then imported AQTESOLV software.

\subsection{DATA ANALYSIS}

Aquifer tests were evaluated by fitting analytical solutions for pumping tests to measured data (Kruseman \& de Ridder 1990) using AQTESOLV for Windows V4.5 (Duffield, 2008). AQTESOLV applies the principle of superposition in time to simulate variable-rate pumping tests including recovery, which treats the variable rate as a sequence of steps in which the discharge rate is constant in each step. AQTESOLV provides a flexible, user-friendly environment with automatic type curve fitting to a data set. Where an automatic curve fit does not yield satisfactory results, data was manually fitted to the type curve using parameter controls based on our knowledge of the geologic and hydrogeologic setting.

Theis's, Cooper-Jacob's, Papadopolus-Cooper's and Theis's recovery methods described by (Kruseman \& de Ridder 1990) were used to calculate the aquifer hydraulic properties. Cooper-Jacob's, Theis's and Theis's recovery methods were used because they are the commonly applied methods for pumping test analysis. A Papadopolus-Cooper method was used because it is the recommended method for analysis of single-well analysis. The method also takes into account well-bore storage. Transmissivity was obtained from software results directly while hydraulic conductivity was calculated based on the relationship between hydraulic conductivity and transmissivity.

A statistical analysis was performed to determine the variation of aquifer transmisivity obtained from different methods using one-way analysis of variance (ANOVA) with $\mathrm{p}<0.05$. According to Verbovšek (2008), hydraulic parameters belong to lognormal distribution, therefore the data was therefore log transformed and analyzed using PAST software (Hammer et al., 2001).

\section{RESULTS}

The transmissivity values ranged between 1.11 and 360.58 $\mathrm{m}^{2} / \mathrm{d}$ by Theis method and Cooper-Jacob method, 1.10 and $360.58 \mathrm{~m}^{2} / \mathrm{d}$ by Papadopulos-Cooper method and 1.289 to $677.81 \mathrm{~m}^{2} / \mathrm{d}$ by Theis recovery method. The lowest transmissivity value was recorded at Kangemi chief's camp borehole while the highest transmissivity was recorded at Pilli management consultant Limited for Theis, CooperJacob and Papadopulos- Cooper methods and Camilla Elizabeth Held for Theis recovery method. Detailed results of the aquifer tests for each well are presented in Figure 2. The statistical summary of transmissivity values from all the four methods are compiled in Table 1 whereas Table 2 gives a statistical summary of the log transformed transmissivities. The values of hydraulic conductivity recorded range between 0.011 and $3.84 \mathrm{~m} /$ day (Figure 3 ). Kangemi chief's camp borehole recorded the lowest hydraulic conductivity while highest hydraulic conductivity was recorded at Pili management consultant limited. Specific capacity ranged between 1.24 and $248.73 \mathrm{~m}^{2} /$ day and is presented in Figure 4.

The eastern side of the city is characterized by higher hydraulic properties than the western side as shown in Figures 2, 3 and 4.

After analysis using ANOVA, the confidence level (p) was found to be 0.87 implying that the mean obtained from set of results using different methods of transmissivity evaluation are not significantly different.

\section{DISCUSSION}

Transmissivity in the Nairobi phonolite is higher than that obtained from the trachytes. This difference could be as a result of lacustrine deposits intercalated with the lavas (Gevaerts, 1964) which improve transmissivity. Hydraulic properties of the aquifer is also influenced by faults as observed in boreholes Waithaka D.O's camp borehole which is located in Karura trachyte but has relatively high transmissivity as compared to other wells in the same geology. The same observation is made on Camila Elizabeth Held borehole which is located is Kerichwa valley sediments.

Using Krásný (1993) standards for transmissivity, the aquifer generally has low to high transmissivity capacity that provides withdrawals for local water supply (private consumption) to withdrawal of lesser regional importance. Areas of intermediate transmissivity can be used for local water supply i.e. small communities and plants.

Based on Krásný (1993) classification of transmissivity variation, the aquifer can be classified as moderate (fairly heterogeneous). This classification was done after determining standard deviation of index of transmissivity (Y) by determining logarithm of transmissivity (Krásný, 1993). Based on both standards for transmissivity and transmissivity variation, the aquifer can be classified into three classes: IIC (high transmissivity with moderate variation), IIIC (intermediate transmissivity with moderate variation) and IVC (low transmissivity with moderate variation). The aquifer has moderate prospects of striking groundwater; however, areas of high and moderate transmissivity are the best for future prospects.

Some of the obtained storativity are not reliable because there were no observation wells during test pumping.

\section{Specific Capacity and Transmissivity}

Based on the Dupit-Thiem equation, Fetter (2001) and Verbovšek (2008) established an empirical relationship between the transmissivity $(\mathrm{T})$ and the specific capacity (q) of the form:

$$
\mathrm{T}=\mathrm{C} \cdot \mathrm{q}^{\mathrm{a}}
$$

where $\mathrm{C}$ and a are constants that are empirically determined from available data sets of $\mathrm{T}$ and $\mathrm{q}$

If such a non-linear empirical relationship can be established it may be used as a rough estimate of $\mathrm{T}$ when full aquifer test analysis for a well is not available (Fetter, 2001).

From this study, a relationship between $\mathrm{T}$ and $\mathrm{q}$ was established from 86 data points as follows: 


$$
\mathrm{T}=1.36 * \mathrm{q}^{0.9316}
$$

if $\mathrm{T}$ is given in $\mathrm{m}^{2} / \mathrm{d}$ and $\mathrm{q}$ in $\mathrm{m}^{3} / \mathrm{day} / \mathrm{m}$.

Possible errors during the pumping tests may involve discharge measurement. Discharge measurement involved two people, one reading stop watch while the other checking if the measurement container is full. This might have been erroneous due to improper coordination of the involved parties. This could be common for the initial readings because they are taken after a short interval of time. Other error includes not maintaining a constant pumping rate as the pumping rate decreases as drawdown increases. However, when these data are plotted serious mistakes can be identified as they will not fall well along the curves.

During data analysis, potential error is attributed to the researcher's judgment in curve fitting. The curve fitting was done manually in AQTESOLV and errors on the part of data interpreter were inherent. The accuracy of a curve or line fitted by visual inspection cannot be determined.

There is no way to properly estimate the storativity value from empirical data because no observation wells were available.

\section{CONCLUSION}

Aquifer sustainability is threatened by increasing water abstraction which is to disadvantage of the future generations. Hydraulic parameters derived from aquifer test data are a good indicator of the quantity of the water that can be abstracted from the aquifer.

The evaluation of hydraulic properties of the aquifer in Nairobi area reveals that the area has moderately good groundwater potential. The aquifer can be classified as moderately heterogeneous with moderate transmissivity variation based on the guidelines by Krásný (1993).

High variation of the aquifer hydraulic properties at different parts can be attributed to structural geological differences in the aquifer for example fracturing and contact between different geological units.

From the results, an empirical relationship between transmissivity and specific capacity has been established. The relationship is significant in that it can be used to derive approximate values of transmissivity in cases where full aquifer test is lacking.

It is recommended that future borehole drilling should be done on the eastern, northern and south eastern sections of Nairobi because they have high transmissivity hence higher maximum sustainable yields. The sections towards western and south western of the city recorded relatively low transmissivity hence lower maximum sustainable yields and should therefore be avoided be for future drilling.

\section{ACKNOWLEDGEMENT}

Special thanks to DAAD (Deutscher Akademischer Austauschdienst) for providing fund for data collection of this study. Without this support, this study would not have been possible. We are also grateful to Ministry of Water and Irrigation, Kenya for providing us with data for this study.

\section{REFERENCES}

[1] CBS (2001): Population and Housing Census. Counting Our People for Development Vol.1. Central Bureau of Statistics, Nairobi.

[2] CBS (2003a): Kenya Demographic and Health Survey 2003. Central Bureau of Statistics, Nairobi.

[3] CCN (2007): City of Nairobi Environment Outlook. City Council of Nairobi, United Nations Environment Programme and the United Nations Centre for Human Settlement, $86 \mathrm{pp}$.

[4] Coetsiers, M., Kilonzo, F., and Walraevens, K. (2008): Hydrochemistry and source of high fluoride in groundwater of the Nairobi area, Kenya, Hydrological Sciences Journal, 53:6, 1230-1240

[5] Darcy, H. (1856): Les fontaines publiques de la ville de Dijon.Paris:Victoria Dalmont.

[6] Davis, J.C. (1986): Statistics and data analysis in geology, $2^{\text {nd }}$ edn. Wiley, New York

[7] Delleur, J.M. (1999): The handbook of Groundwater Engineering. CRC press LLC, Boca Raton, FL.

[8] Duffield, G.M. (2008): AQTESOLV for Windows, Aquifer Test Analysis Software, Ver. 4.50 Professional. ARCADIS Geraghty and Miller Inc., Virginia, U.S.A.

[9] Fetter, C. W. (2001): Applied Hydrogeology. $4^{\text {th }}$ Ed. Prentice-Hall, Upper Saddle River, New Jersey, 598p.

[10]Foster, S. and Tuinhof A., (2005): Sustainable Groundwater management. Concepts and Tools. Kenya: The Role of Groundwater in the Water-Supply of Greater Nairobi. Case Profile Collection No. 13. $\mathrm{GW} \cdot \mathrm{MATE}$ (Groundwater Management Advisory Team). The World Bank, Washington D.C.

[11] Gevaerts E.A. L. (1964): Hydrogeology of Nairobi Area, Technical Report, Survey of Kenya.

[12] Hammer, Ø., Harper, D.A.T., and Ryan, P. D. (2001): PAST: Paleontological Statistics Software Package for Education and Data Analysis. Palaeontologia Electronica 4(1): 9pp.

[13] Jacob, C.E. (1947): Drawdown test to determine effective radius of artesian well. Trans. Amer. Soc. of Civil. Engrs., Vol. 112, Paper 2321, pp. 1047-1064.

[14] Kenya Meteorological Department (2001): The climate of Nairobi city and surrounding areas.

[15] Kenya State of the Environment and Outlook (2010) Supporting the Delivery of Vision 2030. A publication of National Environment Management Authority, 2011. First published 2011

[16]Krásný, J. (1993): Classification of transmissivity magnitude and variation. Groundwater. J. Assoc. Groundwater Scientists Eng., 31:230-236.

[17] Kruseman, G.P. and de Ridder N.A. (1990): Analysis and Evaluation of Pumping Test Data $2^{\text {nd }}$ Ed. (Completely Revised) ILRI publication 47. Intern. Inst. for Land Reclamation and Improvements, Wageningen, Netherlands, 377 pp.

[18] Mitullah, W. (2003): Understanding Slums: Case Studies for the Global Report on Human Settlements 2003: The Case of Nairobi, Kenya. UN-HABITAT, Nairobi. 
[19]MWI/WSP (2005): Focus on Water Sector Reforms. Premier Issue February 2005. Ministry of Water and Irrigation (MWI) and Water and Sanitation ProgramAfrica (WSP), Nairobi.

[20]Nair, K.R., Manji, F., Gitonga, J.N. (1984). The occurrence and distribution of fluoride in groundwaters of Kenya. Challenges in African Hydrology and Water Resources (Proceedings of the Harare Symposium, July 1984). 1AHS Publ. no. 144.

[21]Ngecu, W.M. and Gaciri, S.J. (1998): Urbanization impact on the water resources with major Third World cities: A case study for Nairobi and its environs. Episodes, Vol. 21, no. 4.

[22] Onyancha C., Mathu E., Mwea S. and Ngecu W. (2011): A Study on the Engineering Behaviour of Nairobi Subsoil. ARPN Journal of Engineering and Applied Sciences vol. 6, NO. 7, July 2011.
[23] Saggerson E. P. (1964): Geology of the Nairobi Area, Degree Sheet No. 51, Survey of Kenya.

[24] Theis, C.V. (1935): The relation between the lowering of the piezometric surface and the rate and Duration of discharge of a well using groundwater storage. Trans. Amer. Geophys. Union, Vol. 16, pp. 519-524.

[25] Verbovšek, T. (2008): Estimation of transmissivity and hydraulic conductivity from specific capacity and specific capacity index in dolomite aquifers. Journal of Hydrologic Engineering, Vol. 13, No. 9. ISSN 1084 0699/2008/9-817-823.

[26] World Bank (2004): The Republic of Kenya. Towards a Water-Secure Kenya Water Resources Sector Memorandum Water and Urban I Africa Region.

\section{Figures}

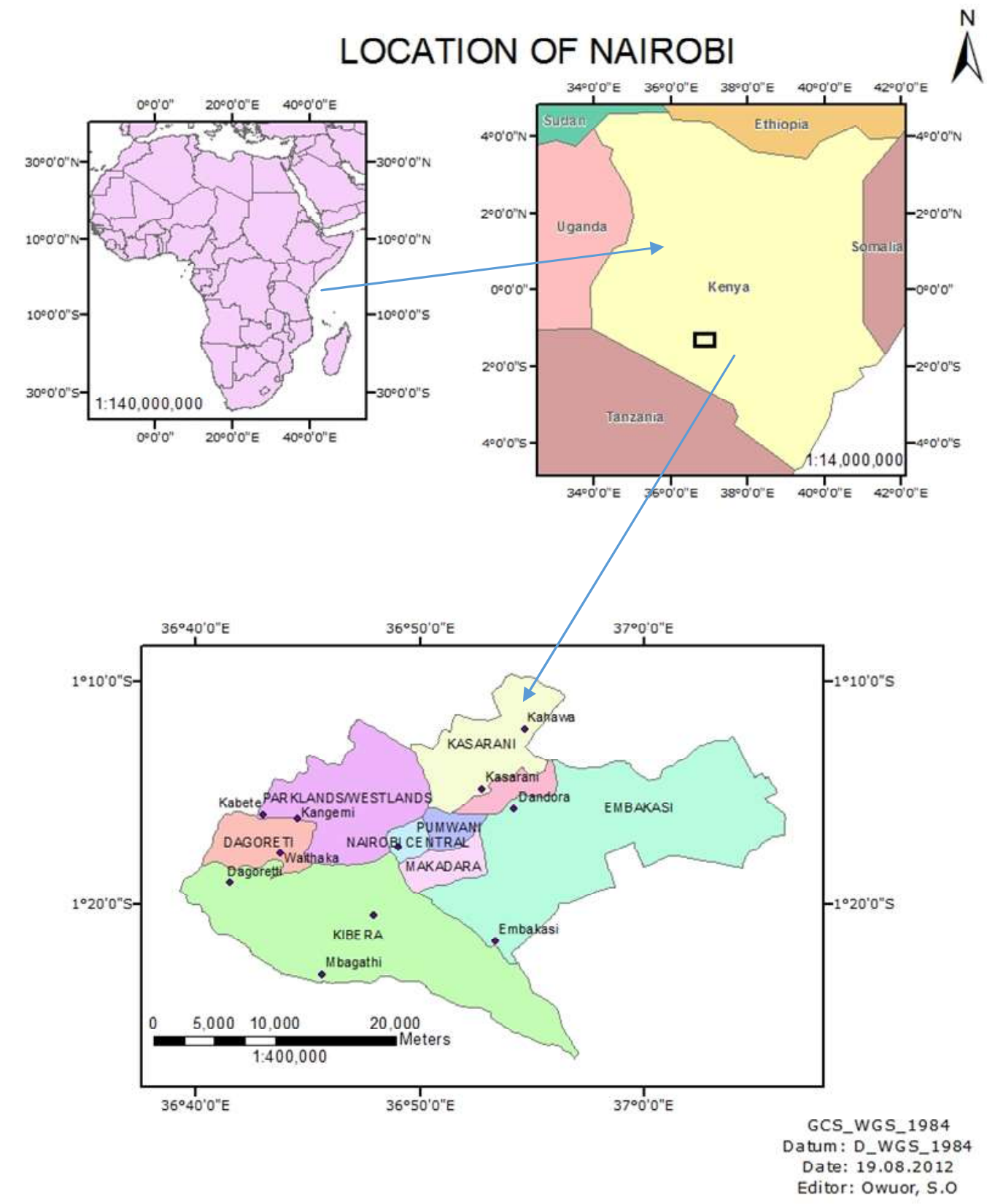

Figure 1: Position of Nairobi City (Modified from ESRI, 2010 and CCN, 2007). 


\section{TRANSMISSIVITY VALUES OF NAIROBI AREA}

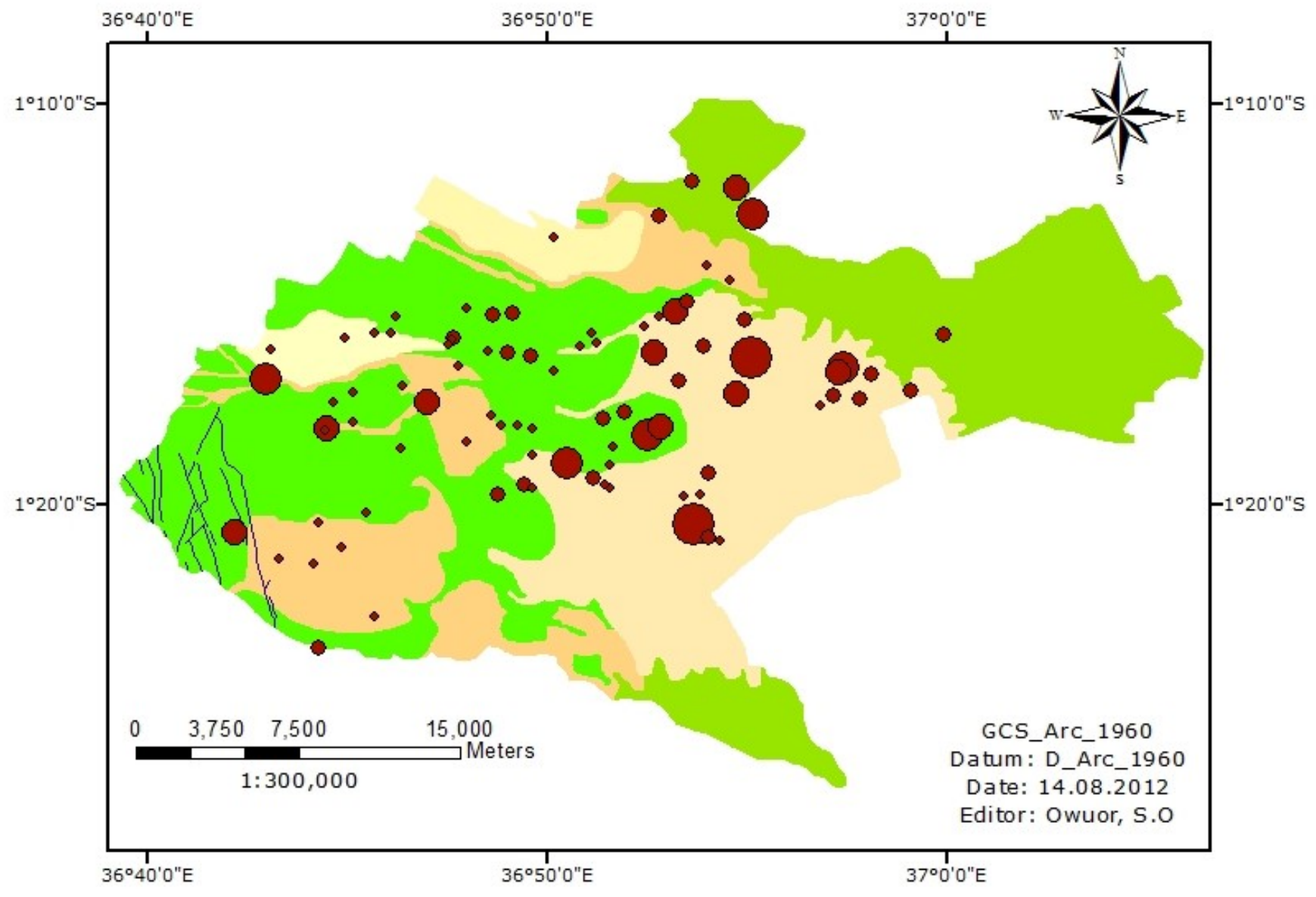

\section{Geology}

Lim uru Trachyte

Karura Trachyte

Kerichwa valley sedim ents

Nairobi Trachyte

Nairobi Phonolite

Mbagathi Trachyte

Upper Athi Series (UAS)

Faults

\section{Transmissivity values of Nairobi area $\left(\mathrm{m}^{2} / \mathrm{day}\right)$}

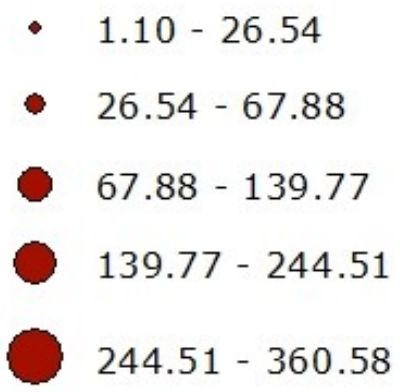

- $1.10-26.54$

- $26.54-67.88$

$67.88-139.77$

$244.51-360.58$

Figure 2: Map of transmissivity values of Nairobi area $\left(\mathrm{m}^{2} /\right.$ day). 


\section{HYDRAULIC CONDUCTIVITY VALUES OF NAIROBI AREA}

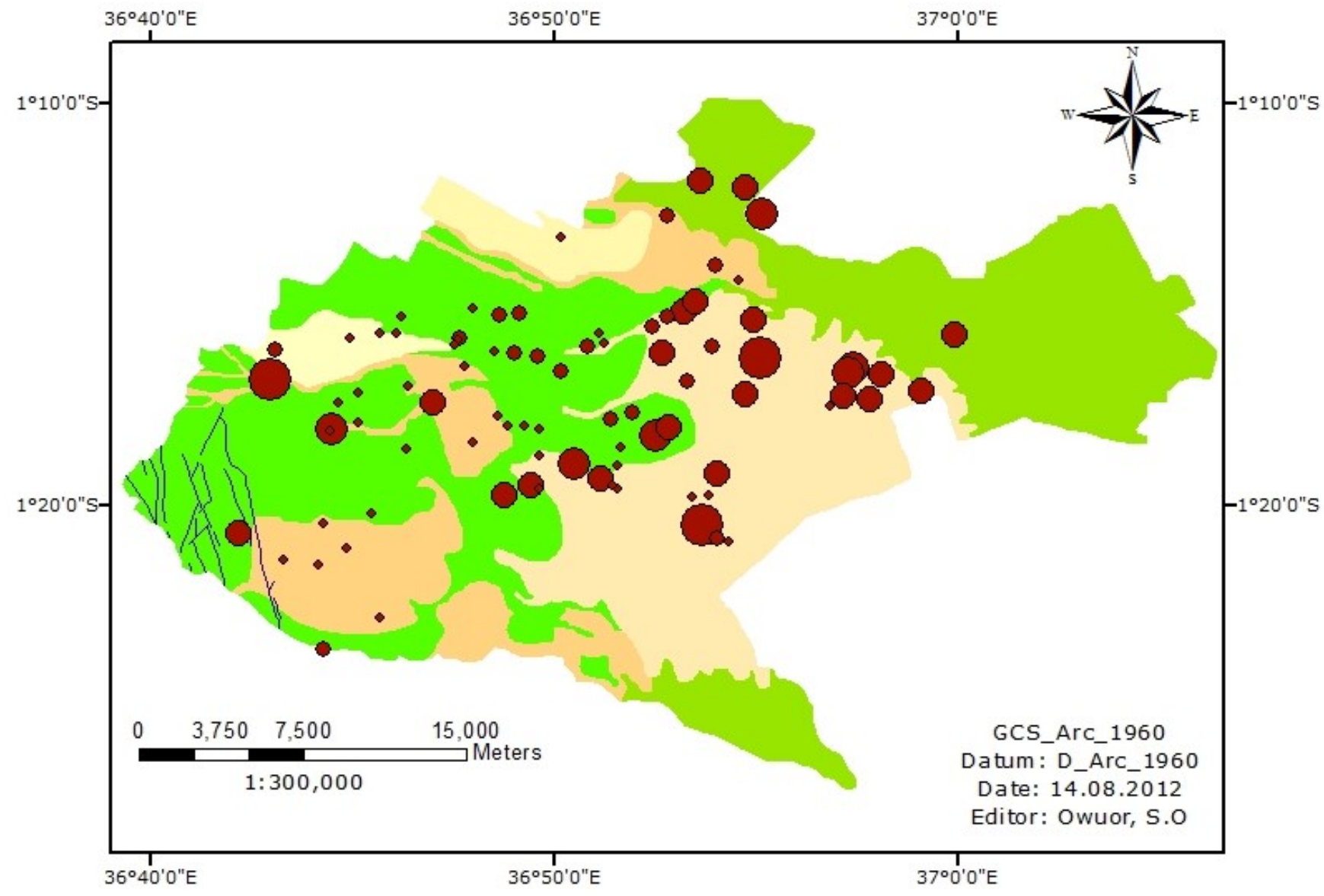

\section{Geology}

Lim uru Trachyte

Karura Trachyte

Kerichwa valley sedim ents

Nairobi Trachyte

Nairobi Phonolite

Mbagathi Trachyte

Upper Athi Series (UAS)

Faults
Hydraulic conductivity values of Nairobi area (m/day)

- $0.01-0.21$

- $0.21-0.56$

$0.56-1.20$

$1.20-2.46$

$2.46-3.84$

Figure 3: Map of hydraulic conductivity values of Nairobi area (m/day). 


\section{SPECIFIC CAPACITY VALUES OF NAIROBI AREA}

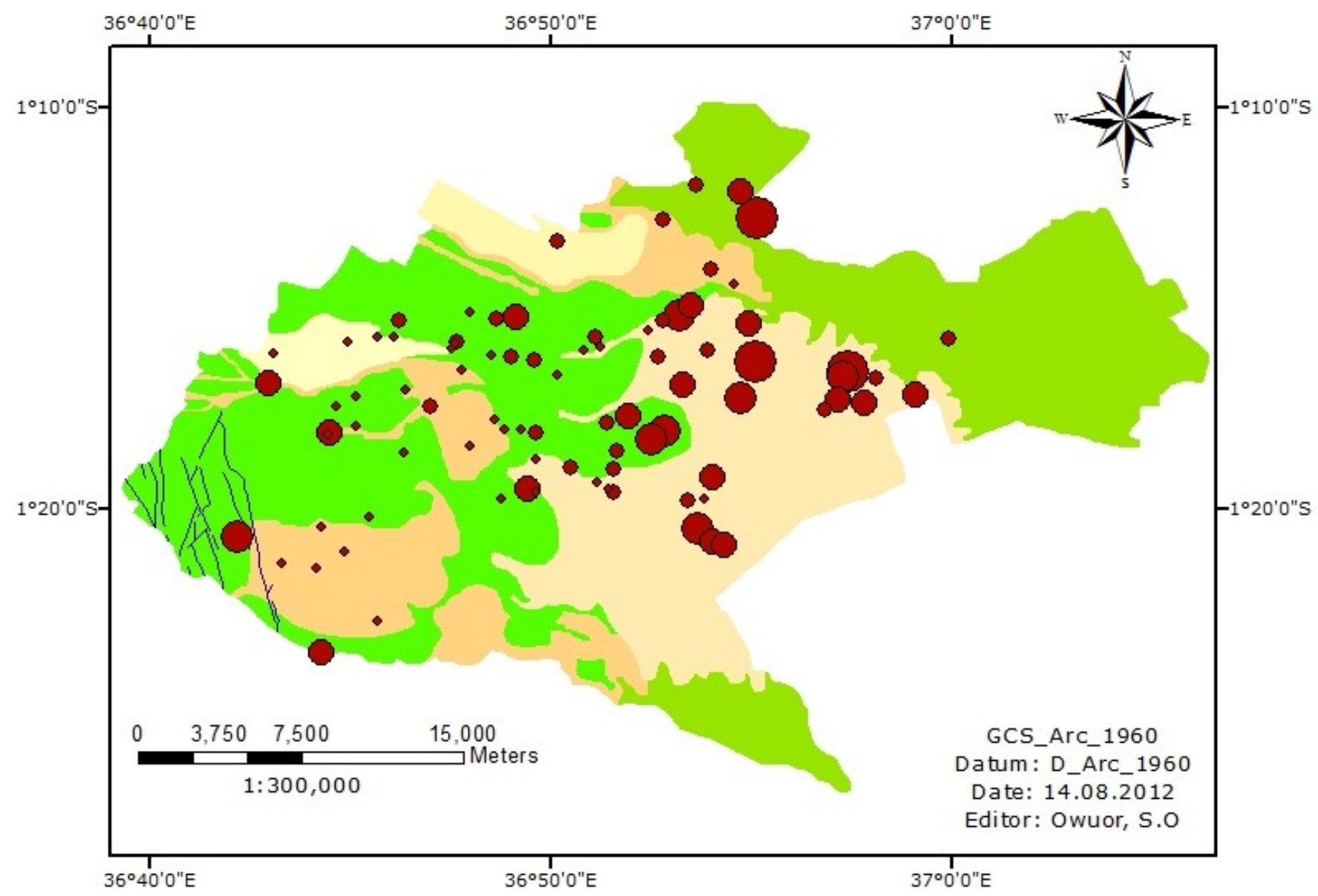

\section{Geology}

Lim uru Trachyte

Karura Trachyte

Kerichwa valley sedim ents

Nairobi Trachyte

Nairobi Phonolite

Mbagathi Trachyte

Upper Athi Series (UAS)

Faults
Specific capacity values of Nairobi area $\left(\mathrm{m}^{2} / \mathrm{day}\right)$
- $1.24-17.62$
- $17.62-40.53$
$40.53-84.38$
$84.38-140.59$
$140.59-248.73$

Figure 4: Map of specific capacity values of Nairobi area $\left(\mathrm{m}^{2} /\right.$ day $)$. 


\section{Tables}

Table 1: Statistical summary of transmissivity estimates from different methods for Nairobi area

\begin{tabular}{|l|l|l|l|l|}
\hline & Theis $\left(\mathrm{m}^{2} /\right.$ day $)$ & Cooper- Jacob $\left(\mathrm{m}^{2} /\right.$ day $)$ & Papadopulos-Cooper $\left(\mathrm{m}^{2} /\right.$ day $)$ & Theis recovery $\left(\mathrm{m}^{2} /\right.$ day $)$ \\
\hline $\mathrm{N}$ & 84 & 84 & 84 & 84 \\
\hline Min & 1.11 & 1.11 & 1.10 & 1.29 \\
\hline Max & 360.58 & 360.58 & 360.58 & 677.81 \\
\hline Mean & 48.90 & 49.23 & 50.63 & 58.50 \\
\hline Std. error & 7.65 & 7.44 & 7.53 & 11.13 \\
\hline Variance & 4911.51 & 4644.24 & 4758.95 & 10408.74 \\
\hline Stand. dev & 70.08 & 68.15 & 68.99 & 102.02 \\
\hline Median & 22.25 & 24.077 & 24.36 & 22.42 \\
\hline 25 prcntil & 9.53 & 9.53 & 11.69 & 7.79 \\
\hline 75 prcntil & 49.54 & 50.22 & 56.35 & 60.33 \\
\hline Skewness & 2.68 & 2.62 & 2.66 & 3.77 \\
\hline Kurtosis & 7.53 & 7.57 & 7.86 & 17.51 \\
\hline Geom. mean & 23.23 & 23.73 & 25.25 & 21.36 \\
\hline
\end{tabular}

Table 2: Statistical summary of log transformed transmissivity values from different methods for Nairobi area

\begin{tabular}{|l|l|l|l|l|}
\hline & Theis $\left(\mathrm{m}^{2} /\right.$ day $)$ & $\begin{array}{l}\text { Cooper-Jacob } \\
\left(\mathrm{m}^{2} / \mathrm{day}\right)\end{array}$ & $\begin{array}{l}\text { Papadopulos- } \\
\text { Cooper }\left(\mathrm{m}^{2} / \mathrm{day}\right)\end{array}$ & $\begin{array}{l}\text { Theis recovery } \\
\left(\mathrm{m}^{2} / \mathrm{day}\right)\end{array}$ \\
\hline $\mathrm{N}$ & 84 & 84 & 84 & 84 \\
\hline Min & 0.045 & 0.045 & 0.041 & 0.11 \\
\hline Max & 2.56 & 2.56 & 2.56 & 2.83 \\
\hline Mean & 1.37 & 1.38 & 1.41 & 1.33 \\
\hline Std. error & 0.059 & 0.059 & 0.058 & 0.07 \\
\hline Variance & 0.29 & 0.30 & 0.28 & 0.42 \\
\hline Stand. dev & 0.54 & 0.54 & 0.53 & 0.65 \\
\hline Median & 1.35 & 1.38 & 1.39 & 1.35 \\
\hline 25 prcntil & 0.98 & 0.98 & 1.07 & 0.89 \\
\hline 75 prcntil & 1.70 & 1.70 & 1.75 & 1.78 \\
\hline Kurtosis & -0.26 & -0.33 & -0.26 & -0.53 \\
\hline Geom. mean & 1.22 & 1.23 & 1.26 & 1.1 \\
\hline
\end{tabular}

